\title{
Extension of Rotifer (Brachionus Plicatilis) Inclusions in the Larval Diets of Mud Crab, Scylla Paramamosain (Estampodor, 1949): Effects on Survival, Growth, Metamorphosis and Development Time
}

\author{
Ong Moc Quy ${ }^{1,2}$, Ravi Fotedar ${ }^{1} \&$ Ho Thi Truong Thy ${ }^{2}$ \\ ${ }^{1}$ Department of Environment and Agriculture, Curtin University, Kent Street, Bentley, Perth, Western Australia \\ 6102, Australia \\ ${ }^{2}$ Department of Aquaculture, Faculty of Fisheries, Nong Lam University, Linh Trung Ward, Thu Duc District, \\ Ho Chi Minh City, Vietnam \\ Correspondence: Ong Moc Quy, Department of Environment and Agriculture, Curtin University, Kent Street, \\ Bentley, Perth, Western Australia 6102, Australia. E-mail: mocquyts@yahoo.com.vn
}

Received: November 23, 2017

Accepted: December 3, 2017

Online Published: December 25, 2017

doi:10.5539/mas.v12n1p65

URL: https://doi.org/10.5539/mas.v12n1p65

\begin{abstract}
The study evaluated the effects of extended dietary inclusions of rotifers (Brachionus plicatilis) on the survival, metamorphosis rate, growth and development time in the larvae of mud crabs (Scylla paramamosain). The five most commonly published feeding regimes of mud crab (S. paramamosain) larvae were selected and tested by including rotifers onto them. Mud crab larvae in the first feeding regime were fed exclusively with Artemia nauplii (control or regime A), while those in feeding regimes 2, 3, 4 and 5 were fed rotifers starting from zoea 1 (Z1) to various development stages of mud crab larvae whereas feeding with Artemia nauplii was commenced from the Z2 stage until the end of the trial (megalopa stage). The results of the larval feeding trial for 24 days of culture showed the progressive decrease in survival of the larvae in all feeding regimes. Extended inclusion of rotifer feeding until Z5 stage resulted in significantly higher survival than in the control from 18 day after hatching onwards. Larval survival was negatively correlated ( $\mathrm{R}^{2}$ from 0.78 to 0.90$)$ with the rearing time; however, different feeding regimes had no significant effect on this correlation. Extending inclusion of rotifer feeding until the Z3, Z4 and Z5 stages resulted in higher percentages of megalopa metamorphosis than in regime control, but did not significantly impact development time, carapace width, body length and wet weight of megalopa.
\end{abstract}

Keywords: Mud crab, Scylla paramamosain, Artemia, rotifer-extension, hatchery, larval feeding regime

\section{Introduction}

Mud crabs belong to the Portunidae family, with the genus Scylla including some of the largest species, such as Scylla serrata, S. tranquebarica, S. paramamosain and S. olivacea (Keenan, 1999b). Scylla spp. are distributed throughout the tropical and subtropical Indo-Pacific, from South Africa to Tahiti, around the North to Okinawa and the South to Port Hacking in Australia (Keenan, Davie \& Mann, 1998; Keenan, 1999a). In Vietnam, mud crab cultivation was first introduced to coastal provinces in 1993, mostly in the Mekong Delta (Dat, 1999). Scylla paramamosain is the dominant species among the four Scylla species (Keenan et al., 1998) and the second most common crustacean species, after the shrimp, reared in the coastal areas of Vietnam (Nghia et al., 2007). Mud crab aquaculture mainly relies on wild-caught seed (Keenan, 1999a), hatchery-raised seed production is unreliable and inconsistent (Heasman \& Fielder, 1983) leading to higher and non-viable prices (\$/crablet). Though, lately mud crab hatcheries are using umbrella-stage of Artemia incubated for 7 to 9 hours of the cyst (Vinh Chau, Vietnam) to feed zoea 1, yet with inconsistent success.

Recently, the demand for alternative species to shrimp, such as mud crabs, has increased, mainly as a result of the early mortality syndrome (EMS), which adversely affects shrimp production in Vietnam (Vietnam, 2013). The consequent increase in demand has put more pressure on the supply of mud crab seeds. This pressure has further intensified due to the dwindling supply of wild mud crab seed, shifting the emphasis on the production of seed in the hatcheries. However, hatchery production technology has mainly focused on S. serrata (Baylon \& Failaman, 1999; Mann, Asakawa \& Pizzutto, 1999; Quinitio, Parado-Estepa \& Alava, 1999; Davis, 2003; Yi, Lee 
\& Lee, 2009; Hassan, Hai, Anil \& Sukumaran, 2011), while a limited research is available on the seed production of $S$. paramamosain (Zeng \& Li, 1999; Nghia et al., 2007), especially on feeding regimes. Previous research has confirmed that rotifers and Artemia nauplii are the most acceptable and convenient live feed organisms in larval rearing of various commercial species of the Portunidae family. However, information about the time of withdrawal of rotifers from the larval feeding regime is ambiguous and contradicting. For example, Baylon and Failaman (1999), Faleiro and Narciso (2009) and Redzuari et al. (2012) have stated that rotifers should be fed throughout the zoeal stage to enhance larval survival, whereas Nghia (2004) and Ruscoe, Williams and Shelley (2004b) have suggested that rotifer feeding should be limited to the zoeal 1 (Z1) stage. The reason for limited rotifer use seems to be based on the complexities associated with the mass production techniques of rotifers, which involves substantial use of floor space, significant costs for microalgae and labour, danger of infections and unpredictable crashes during commercial rotifer production (Nghia, 2004; Ruscoe et al., 2004b).

The rotifer production protocol modified by Lind (2014) and Kostopoulou, Vasilakis and Divanach (2012) is considerably streamlined process, resulting in a high daily rotifer productivity, high growth rates, absence of ciliates, low concentrations of total Vibrio (Lind, 2014), prolonged culture time without any crashes and a low production cost, leading to straightforward feeding management protocol (Kostopoulou et al., 2012).

Artemia nauplii have traditionally been used in feeding regimes of most of the mud crab larvae, albeit with mixed outcomes (Baylon, 2009; Dan et al., 2016b). However, due to the advances in practicability of rotifer production techniques and the inconsistent quality and higher costs associated with Artemia production in the hatcheries, the increased use of rotifers in S. paramamosain hatcheries could be considered as an improvement in larval production techniques and reducing in production costs. To understand clearly a role of rotifers inclusions along with the Artemia, the current study aimed to evaluate the extended use of rotifer inclusions in the feeding regimes of mud crab larvae in a commercial megalopa production under the hatchery environment. The evaluation of the feeding regimes was based on the survival improvement, metamorphosis rate, growth and development time of the larvae.

\section{Materials and Methods}

\subsection{Water Source}

To minimise infections from the seawater supply, the seawater was pumped into a settling reservoir one day prior to the disinfection with $20 \mathrm{mg} \mathrm{L}^{-1}$ calcium hypochlorite. After 48 hours of chlorination, the seawater was pumped into a storage tank where no chlorine residue was detected by the colorimetric method. Prior to the experiment, the seawater in the storage tank was pumped into a $60-\mathrm{L}$ plastic bucket and disinfected again with $2 \mathrm{mg} \mathrm{L}^{-1}$ Vikor-S (Bayer, Germany); the treated seawater was then used daily in the experiment.

\subsection{Rotifers and Artemia Culture}

Rotifers (Brachionus plicatilis, L-strain, $250 \mu \mathrm{m}$ (Daintith, 1996)), obtained from the marine fish hatchery in Vung Tau Province, Vietnam (10 $24^{\prime} 51^{\prime \prime N}$; $\left.107^{\circ} 10^{\prime} 38^{\prime \prime} \mathrm{E}\right)$, were cultured in an indoor 4000-L square concrete tank filled with disinfected seawater (30\%) and supplied with gentle aeration. The rotifers were fed three times ( $6 \mathrm{am}, 12 \mathrm{pm}$ and $6 \mathrm{pm}$ ) daily with an equal proportion of baker's yeast and commercially available rotifer diet (S.parkle, INVE Aquaculture, Thailand), following the protocol described by Lind (2014). At six to seven days post-rearing, the rotifers had achieved a density of approximately 500 individuals $\mathrm{mL}^{-1}$ and were harvested by using $60-\mu \mathrm{m}$ filter bags.

Individuals of Artemia franciscana (Vinh Chau strain, Vietnam), one of the smallest strains of Artemia, were soaked in fresh water for one hour to absorb water before being disinfected with sodium hypochlorite at a concentration of $20 \mathrm{mg} \mathrm{L}^{-1}$ for 10 minutes under aeration. The cysts were then washed with seawater and placed into an incubation container filled with disinfected seawater (30\%). Strong aeration was continuously provided. The incubation setup was exposed to natural light for 12 hours, a temperature of $28-30^{\circ} \mathrm{C}$ and a $\mathrm{pH}$ of $8.0-8.3$. After 15 hours of incubation, newly hatched Artemia nauplii were harvested as feed for mud crab larvae.

\subsection{Source of Brood Stock and Larvae}

Mature females of S. paramamosain, weighing 400 to $500 \mathrm{~g}$, were collected from extensive shrimp farms in the Nam Can district, Ca Mau Province, Vietnam ( $8^{\circ} 45^{\prime} 00^{\prime \prime} \mathrm{N}$; $\left.105^{\circ} 01^{\prime} 38^{\prime \prime} \mathrm{E}\right)$, and transported to the hatchery in the same area. Prior to the stocking, the female crabs were washed and disinfected by $100 \mu \mathrm{L} \mathrm{L}^{-1}$ of formalin solution under aeration for 1 hour and finally stocked individually in 30-L plastic buckets to exclude cannibalism. The buckets were filled up to $40 \%$ volume of $1 \mu \mathrm{m}$ filtered and disinfected seawater (30\%). Each bucket was provided with strong aeration. After one day of acclimation, female crabs were subjected to unilateral eyestalk ablation to stimulate spawning. Each crab was then placed back into the same bucket and fed once in the evening 
with 10 to $20 \mathrm{~g}$ of fresh bivalve (Anadara granosa) meat. Daily water change at $200 \%$ by volume was conducted in the morning and two hours after each feeding. Ambient temperature and photoperiod were $28-30^{\circ} \mathrm{C}$, and 12 light: 12 dark hours, respectively. Just before spawning behaviour set in as indicated by opening and washing of pleopod hair under the abdomen, the female crabs were transferred to a 60 -L plastic bucket with a 10 -cm layer of sand as substrate. Spawning occurred in these buckets.

Berried females were transferred into plastic boxes $(35 \times 60 \times 40 \mathrm{~cm}$, width, length and height) which were immersed into a 2000-L square fibre-glass tank attached to a sand filtration system to filter and reuse water. The females were reared individually. During the incubation period, the females were starved until their eggs hatched. Faeces and damaged eggs were siphoned out of the tanks; water was exchanged daily at a rate of $20 \%$. On the $11^{\text {th }}$ day post-spawning, the berried females were transferred to another container in which sea water was diluted with $0.1 \mu \mathrm{L} \mathrm{L}^{-1}$ iodine solution for 2 minutes under aeration to prevent fungal, protozoa and bacterial infections to the eggs. Following this, the berried females were released into a $200-\mathrm{L}$ round incubation tank containing $80 \%$ volume of fresh disinfected seawater for hatching. Temperature, salinity and photoperiod were similar to the previous ambient conditions.

Newly hatched zoea 1 (Z1) from one spawner were concentrated on the water surface after switching off the aeration. The $\mathrm{Z} 1$ were then collected and bathed in $0.1 \mu \mathrm{L} \mathrm{L}^{-1}$ iodine solution for 30 seconds before being distributed into two 100-L plastic buckets. After 2 hours, the larvae in the first bucket were solely fed newly hatched Artemia nauplii at a rate of 5-10 individuals $\mathrm{mL}^{-1}$, termed as regime A (A: Artemia) or control, while the larvae in the second bucket were fed purely rotifers at a rate of 20-40 individuals $\mathrm{mL}^{-1}$, subsequently used as regimes 2, 3, 4 and 5. On the following day, one-day-old larvae were collected for the subsequent experiment.

\subsection{Experimental Setup}

Fifteen 1.5-L plastic beakers were filled with $1 \mathrm{~L}$ of disinfected seawater $(30 \%)$. Each beaker was then stocked with 30 healthy and active one-day-old larvae which were collected from the 100-L plastic bucket. All the experimental beakers were incubated in a 5000-L square concrete tank to maintain a constant temperature of 28 $\pm 1^{\circ} \mathrm{C}$. The beakers were provided with a moderate aeration to prevent settling of larvae and live feed. The light, which attracted crab larvae and live food concentrating on water column and surface, can improve ability of mud crab larvae for catching the prey, so the light was maintained constantly for 24 hours, including 12 hours of natural light and 12 hours of artificial light provided by a $40-\mathrm{W}$ fluorescent globe. The $\mathrm{pH}$ was adjusted approximately to $8.3 \pm 0.2$ by adding $\mathrm{CaCO}_{3}$ and/or $\mathrm{NaHCO}_{3}$.

\subsection{Feeding Regimes}

Five feeding regimes based on inclusion of rotifers at different stages of crab larval development were tested in triplicate. The mud crab larvae, from Z1 to megalopa (M) in regime A (control) were exclusively fed Artemia nauplii (Table 1). From regime 2 onwards (R2-A to R5-A), the rotifer inclusion extended one further stage of larval development from Z1 to the next stage. For example, in R2-A, the rotifer inclusion extended to Z2 stage only followed by Artemia to all remaining stages of larval development from Z2. R3-A constituted rotifer inclusion extended to Z3 stages. Similarly, R4-A and R5-A consisted of rotifer inclusion extended to Z4 and Z5 respectively. From R2-A to R5-A Artemia were provided from Z2 to megalopa stages.

Table 1. Regimes show extending inclusion of rotifers as a live food in the feeding regimes for S. paramamosain larvae

\begin{tabular}{lll} 
& Regime A (control) & Artemia (Z1-M) \\
Regime 2 (R2-A) & Rotifers (extended to Z2) + Artemia (Z2-M) \\
Regime 3 (R3-A) & Rotifers (extended to Z3) + Artemia (Z2-M) \\
Regime 4 (R4-A) & Rotifers (extended to Z4) + Artemia (Z2-M) \\
Regime 5 (R5-A) & Rotifers (extended to Z5) + Artemia (Z2-M) \\
\hline
\end{tabular}

A: Artemia; R: Rotifers; Z: zoea, M: megalopa; number after the letter represents the larval stage.

\subsection{Live Feed Densities in Feeding Regimes}

When mud crab larvae were fed exclusive Artemia nauplii and exclusive rotifers, as per the feeding regime described above (section 2.5), the density was maintained at 10 and 20 individuals $\mathrm{mL}^{-1}$ respectively. If the feeding regime was represented by a mixture of Artemia and rotifers, their respective densities was reduced to 5 and 10 individuals $\mathrm{mL}^{-1}$, respectively. This density regime is based on the previous study of Baylon, Bachoco, Huyo and Gallo (1999). To obtain the desired densities of rotifers and Artemia, every beaker was prepared 
according to the method described by Baylon (2009). The crab larvae were fed only once in the morning after being transferred into a newly prepared beaker filled with disinfected seawater by using a large bore pipette. At the same time, larvae mortality was recorded for each beaker. All environmental parameters in a newly prepared beaker were maintained similar to those in the replaced beaker. As soon as megalopa stage appeared, they were immediately removed from the rearing beaker in order to avoid cannibalism.

\subsection{Data Analysis}

Five megalopa were then fixed in $10 \%$ formalin solution to measure body lengths, carapace widths and wet weights. Final survival, rate of metamorphosis, development time and growth performance of the megalopa stage were recorded at the end of the experiment ( 24 days after hatching). The final survival of the larvae, including zoea and megalopa, was computed using the following equation:

Survival $(\%)=\left(\sum\right.$ Final number larvae x 100)/Initial number of zoea 1 stocked (1)

Megalopa body length and carapace width were measured using a ruler scale inserted into the eyepiece of a microscope (Olympus CX21, USA), according to the method described by Ingle (1997). Wet weight of megalopa was measured using a $0.0001-\mathrm{g}$ precision analytical balance (PA 214-Ohaus, USA).

\subsection{Statistical Analyses}

The data of survival, percentage of successfully metamorphosed megalopa and growth of megalopa were presented as mean and standard error $( \pm \mathrm{SE})$, wherein data presented in percentages were arcsine-square root-transformed (Zar, 2010) prior to analysis. One-way ANOVA was performed to test for significant differences between the regimes; specific differences between means of regimes were detected by Tukey's multiple range test at the 0.05 level of significance. Development time, body length, carapace width and megalopa wet weight were compared using Kruskal-Wallis non-parametric test. In the case of significant differences, Mann-Whitney Test was used to compare means of the regimes at the 0.05 level of significance. All statistical analyses were computed using SPSS for Windows, version 24.0.

\section{Results}

\subsection{Environmental Parameters}

Water temperature in the concrete tank used as a water bath for all experimental beakers ranged from 27 to $30^{\circ} \mathrm{C}$ throughout the experiment. Salinity, $\mathrm{pH}$ and alkalinity were constant at $30 \%, 8.3 \pm 0.2$ and $140 \mathrm{mg} \mathrm{CaCO} \mathrm{L}^{-1}$, respectively. The optimum temperature for zoeal development range from $25-30^{\circ} \mathrm{C}$, while optimal salinity values range from $27-35 \%$ for early larval stages (Z1-Z3) and from $23-31 \%$ for late larval stages of S. paramamosain (Z4-M) (Li et al., 1999) and S. serrata (Baylon, 2010; Dan \& Hamasaki, 2011). Thus, the environmental factors in this experiment were within a normal range for the larval development of mud crabs.

\subsection{Larval Survival}

The survival of the larvae progressively decreased in all regimes (Table 2). Extending inclusion of rotifer feeding until the $\mathrm{Z} 5$ stage resulted in a significantly higher $(\mathrm{P}<0.05)$ survival than that of the control from 18 days after hatching onwards. Survival of the larvae showed negative correlation $\left(\mathrm{R}^{2}\right.$ from 0.78 to 0.90$)$ with the rearing period; however, different feeding regimes had no significant $(\mathrm{P}>0.05)$ influence on this correlation (Table 3 ).

Table 2. Mean survival $( \pm \mathrm{SE})$ of crab larvae fed according to different feeding regimes for 24 days of culture

\begin{tabular}{|c|c|c|c|c|c|}
\hline \multirow{2}{*}{ Days of culture } & \multicolumn{5}{|c|}{ Regimes } \\
\hline & $\mathrm{A}$ & R2-A & R3-A & R4-A & R5-A \\
\hline 3 & ${ }^{1} 70.0 \pm 10.72^{\mathrm{a}}$ & ${ }^{\mathrm{I}} 66.7 \pm 0.00^{\mathrm{a}}$ & $175.6 \pm 4.84^{\mathrm{a}}$ & $172.2 \pm 2.94^{\mathrm{a}}$ & $177.8 \pm 1.11^{\mathrm{a}}$ \\
\hline 6 & ${ }^{12} 44.4 \pm 7.78^{\mathrm{a}}$ & ${ }^{12} 48.9 \pm 4.01^{\mathrm{a}}$ & ${ }^{12} 57.8 \pm 10.94^{\mathrm{a}}$ & ${ }^{\mathrm{I}} 62.2 \pm 2.94^{\mathrm{a}}$ & ${ }^{12} 64.4 \pm 5.88^{\mathrm{a}}$ \\
\hline 9 & ${ }^{23} 28.9 \pm 4.01^{\mathrm{a}}$ & ${ }^{23} 32.2 \pm 2.94^{\mathrm{a}}$ & ${ }^{12} 46.7 \pm 11.71^{\mathrm{a}}$ & ${ }^{12} 50.0 \pm 3.33^{\mathrm{a}}$ & $12354.4 \pm 5.56^{\mathrm{a}}$ \\
\hline 12 & $3418.9 \pm 2.94^{a}$ & ${ }^{34} 23.3 \pm 5.09^{a}$ & ${ }^{12} 38.9 \pm 11.28^{a}$ & ${ }^{23} 35.6 \pm 4.44^{\mathrm{a}}$ & ${ }^{234} 45.6 \pm 6.19^{\mathrm{a}}$ \\
\hline 15 & ${ }^{34} 13.3 \pm 1.92^{\mathrm{a}}$ & ${ }^{34} 16.7 \pm 5.77^{a}$ & ${ }^{12} 34.4 \pm 10.60^{a}$ & ${ }^{23} 32.2 \pm 4.44^{\mathrm{a}}$ & ${ }^{234} 40.0 \pm 5.09^{a}$ \\
\hline 18 & ${ }^{34} 10.0 \pm 1.92^{\mathrm{a}}$ & $\begin{array}{c}{ }^{34} 13.3 \pm 5.09^{\mathrm{ab}} \\
(+3.3)\end{array}$ & $\begin{array}{c}1230.0 \pm 8.82^{\mathrm{ab}} \\
(+20.0)\end{array}$ & $\begin{array}{c}2330.0 \pm 5.09^{\mathrm{ab}} \\
(+20.0)\end{array}$ & $\begin{array}{c}3435.6 \pm 4.84^{\mathrm{b}} \\
(+25.6)\end{array}$ \\
\hline 21 & ${ }^{34} 8.9 \pm 1.11^{\mathrm{a}}$ & ${ }^{4} 11.1 \pm 2.94^{\mathrm{ab}}$ & $\begin{array}{c}{ }^{12} 26.7 \pm 6.94^{\mathrm{ab}} \\
(+178)\end{array}$ & $28.9 \pm 6.19^{\mathrm{ab}}$ & ${ }^{34} 32.2 \pm 4.84^{\mathrm{b}}$ \\
\hline 24 & ${ }^{4} 7.8 \pm 1.11^{\mathrm{a}}$ & $\begin{array}{c}{ }^{4} 10.0 \pm 1.92^{\mathrm{ab}} \\
(+2.2)\end{array}$ & $\begin{array}{c}23.3 \pm 8.82^{\mathrm{ab}} \\
(+15.5)\end{array}$ & $\begin{array}{c}{ }^{3} 25.6 \pm 4.84^{\mathrm{ab}} \\
(+17.8)\end{array}$ & $\begin{array}{c}{ }^{4} 28.9 \pm 4.44^{\mathrm{b}} \\
(+21.1)\end{array}$ \\
\hline
\end{tabular}

The number into (.) shows percentage changed in relation to control in each feeding regime. Significant differences were found among all regimes with different superscript letters $(P<0.05)$ in the same row. Significant differences were also found throughout the culture period within the regime with different superscript numbers $(P<0.05)$ in the same column. 
Table 3. Relationship between the survival and days of culture of crab larvae fed according to different feeding regimes.

\begin{tabular}{lll}
\hline Regimes & Equation & Regression $\left(\mathrm{R}^{2}\right)$ \\
\hline A & $\mathrm{y}=-3.54 \mathrm{x}+76.03$ & $0.78 \pm 0.04^{\mathrm{a}}$ \\
R2-A & $\mathrm{y}=-3.41 \mathrm{x}+76.69$ & $0.82 \pm 0.01^{\mathrm{a}}$ \\
R3-A & $\mathrm{y}=-2.90 \mathrm{x}+82.89$ & $0.86 \pm 0.06^{\mathrm{a}}$ \\
R4-A & $\mathrm{y}=-2.83 \mathrm{x}+82.52$ & $0.85 \pm 0.01^{\mathrm{a}}$ \\
R5-A & $\mathrm{y}=-2.74 \mathrm{x}+86.10$ & $0.90 \pm 0.03^{\mathrm{a}}$ \\
\hline
\end{tabular}

$Y$ represents the survival of larvae and $X$ the day of culture. Values represent mean \pm standard error (SE). Significant differences in regression were found among all regimes with different superscript letters $(P<0.05)$ in the same column.

\subsection{Percentage of Successful Metamorphosis and Development Time to Megalopa}

Extending inclusion of rotifer feeding until the Z3, Z4 and Z5 stages (R3-A, R4-A and R5-A) resulted in a higher $(\mathrm{P}<0.05)$ percentage of metamorphosis of megalopa $(17.8,20.0$ and $27.8 \%$, respectively) than in the control (2.2\%, Fig. 1), while development time of the larvae ranged from 17.0 to 22.5 days and was independent $(\mathrm{P}>$ 0.05) of any feeding regimes (Fig. 2).

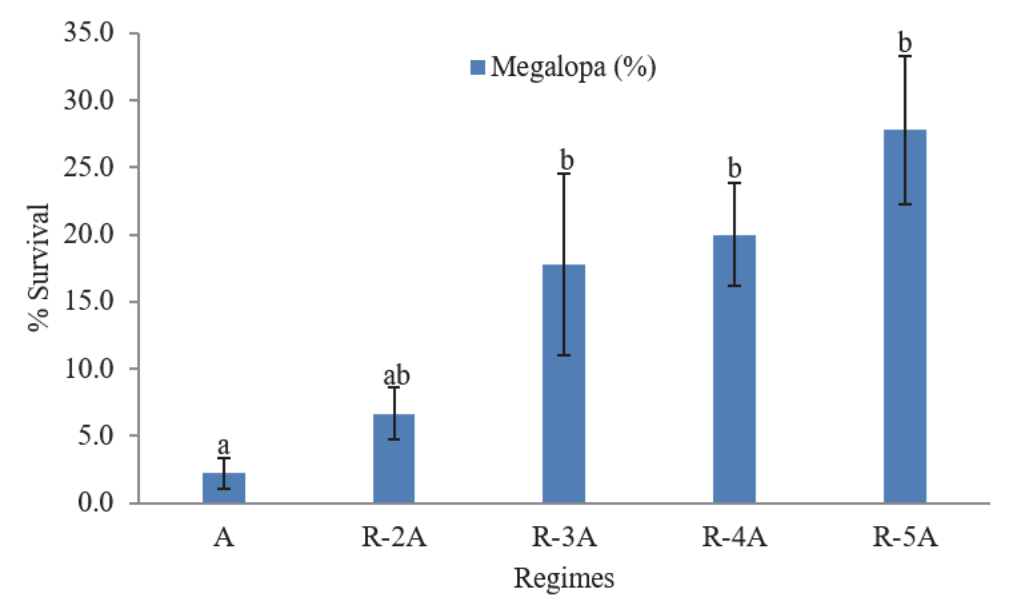

Figure 1. Percentages of successful metamorphosis of megalopa fed according to various feeding regimes Significant differences were found among all regimes with different superscript letters $(P<0.05)$ in the bar chart.

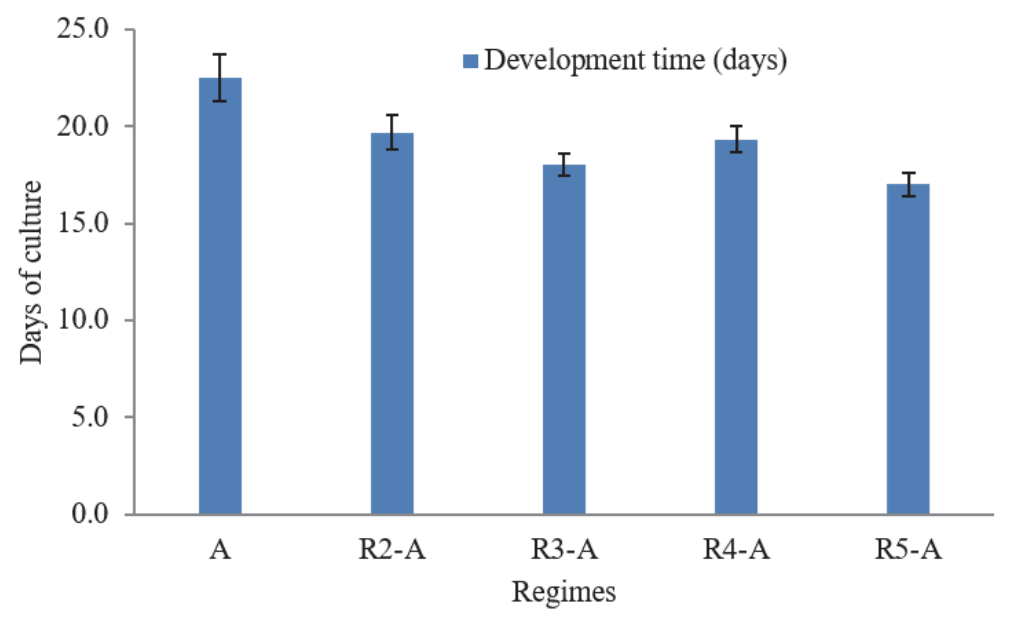

Figure 2. Duration of the period required for metamorphosis from zoeal to the megalopa stage under various feeding regimes. Significant differences were found among all regimes with different superscript letters $(P<$ 0.05) in the bar chart 


\subsection{Growth Performance of Megalopa}

Growth performance of megalopa resulting from zoea fed various feeding regimes ranged of $1.65-1.71 \mathrm{~mm}$ in carapace width, 4.98-5.11 mm in body length and 3.83-4.05 $\mathrm{g}$ in wet weight; however, the growth performance of megalopa did not depend $(\mathrm{P}>0.05)$ on any of the feeding regimes (Table 4$)$.

Table 4. Mean carapace width, body length and wet weight of one-day-old megalopa under different feeding regimes.

\begin{tabular}{llll}
\hline Regimes/Parameters & CW (mm) & BL (mm) & WW (mg) \\
\hline A & $1.65 \pm 0.04^{\mathrm{a}}$ & $5.00 \pm 0.08^{\mathrm{a}}$ & $4.05 \pm 0.61^{\mathrm{a}}$ \\
R2-A & $1.70 \pm 0.01^{\mathrm{a}}$ & $5.03 \pm 0.03^{\mathrm{a}}$ & $4.02 \pm 0.09^{\mathrm{a}}$ \\
R3-A & $1.71 \pm 0.02^{\mathrm{a}}$ & $5.02 \pm 0.06^{\mathrm{a}}$ & $3.83 \pm 0.03^{\mathrm{a}}$ \\
R4-A & $1.68 \pm 0.01^{\mathrm{a}}$ & $5.11 \pm 0.03^{\mathrm{a}}$ & $3.93 \pm 0.04^{\mathrm{a}}$ \\
R5-A & $1.69 \pm 0.02^{\mathrm{a}}$ & $4.98 \pm 0.04^{\mathrm{a}}$ & $3.94 \pm 0.05^{\mathrm{a}}$ \\
\hline
\end{tabular}

CW: Carapace width; BL: Body length; WW: Wet weight. Values represent mean \pm SE. Significant differences were found among all treatments with different superscript letters $(P<0.05)$ in the same column.

\section{Discussion}

The mud crab zoeal instars do not always show synchronised moulting but can extend and overlap with next stage for approximately 1 day (Davis, Wille, Hecht \& Sorgeloos, 2005b). Hence, no larval stage can be designed by a single day due to their non-synchronised moulting, it is relatively clear to depict survival by 'days of culture' rather than by individual development stage as in Table 2. In our study, except the megalopa stage, all larval developing stages took approximately 3 days to complete, whereas megalopa stage took 6-7 days to complete.

A diet composed of rotifers and Artemia has the ability to improve larval survival in S. serrata (Baylon et al., 1999; Nghia, 2004; Ruscoe et al., 2004b), S. paramamosain (Zeng \& Li, 1999) and Thalamita crenata (Godfred, Ravi \& Kannupandi, 1997). In general these studies did not show any potential benefits when rotifer feeding was extended until the late larval stages in portunid crabs, and until the late zoeal stages in S. paramamosain. Under laboratory conditions, our study confirmed the benefits of extending feeding of rotifers until the late zoeal stages in S.paramanmosain seed production.

In the present study, rotifers and Artemia could be considered as first food for early crab larvae, when larvae in all feeding regimes could successfully metamorphosed to next stage, whereas, $100 \%$ of unfed larvae could not moult and died by day 7 (Holme, Zeng \& Southgate, 2006), Similar to our study, rotifers due to their small size, low moving speed, rapid reproduction and an ability to store and contain desired nutrients (Dhert, 1996) are used as first food for early larval stages of mud crabs (Zeng \& Li, 1999; Davis, 2003; Baylon, Bravo \& Maningo, 2004; Nghia, 2004; Ruscoe et al., 2004b; Baylon, 2009; Hassan et al., 2011), swimming crabs (Portunus spp.) (Ikhwanuddin, Azra, Redzuari, Aizam \& Abol-Munafi, 2012; Redzuari et al., 2012; Dan, Ashidate \& Hamasaki, 2016a) and giant freshwater prawn (Macrobrachium rosenbergii) (Barros \& Valenti, 2003). The early crab larvae from Z1 and Z2 achieved a higher survival when rotifers were employed as a first food (Zeng \& Li, 1999; Ruscoe, Shelley \& Williams, 2004a; Ruscoe et al., 2004b; Baylon, 2009); however, feeding only rotifers until the late zoeal stage (Z5) led to a complete mortality at Z5 (Baylon, 2009), delayed larval development (Nghia, 2004) or possible extension to one extra zoeal stage (Z6), as shown by Zeng, Li and Zeng (2004). Due to this reason, our study did not include 'feeding rotifers only' as one of the treatments.

Like rotifers, Artemia nauplii are also acceptable as a first food and the larvae fed Artemia nauplii alone survived and metamorphosed to the megalopa stage in the present study. This result is also in line with the previous studies of Brick (1974), Heasman and Fielder (1983), Baylon et al. (1999) and Davis, Wille, Hecht and Sorgeloos (2005a). We observed that only healthy and active crab larvae could catch and handle Artemia nauplii under the controlled feeding regime, while the weak ones were only able to ingest a few residual parts of the dead Artemia from the bottom of the beaker. As a result, the weak larvae either died or their development time to the megalopa stage was prolonged, induced by on-time failure to metamorphose to the next stage. Thus, demonstrating that the survival of the larvae fed exclusively Artemia dropped rapidly as the study progressed and significant difference was detected at day $9^{\text {th }}$ while the treatments that involved the extension of rotifer inclusion after Z2 were significant from day $12^{\text {th }}$ onwards. Baylon (2009) also stated that the early larval stages are passive predators, so they are unable to pursue and catch larger and fast moving prey including Artemia nauplii (Zeng \& Li, 1999; Nghia, 2004; Baylon, 2009); sometimes, only certain parts, such as the head and appendages of the 
Artemia nauplii, are ingested (Zeng \& Li, 1999; Baylon, 2009). As a result, a low survival rate (7.8\%) and delayed development time (22.5 days) was observed in crab larvae that were exclusively fed Artemia (control) in the present study. Similarly, low survival and prolonged Z6 stage in the ontogenetic development of mud crabs was detected by Zeng et al. (2004); in some cases, the animals even failed to metamorphose beyond the Z5 stage (Suprayudi, Takeuchi, Hamasaki \& Hirokawa, 2002; Nghia, 2004) when only Artemia nauplii were used as a feed. The limited catchability of early zoeal stages implied that Artemia were not a suitable food for early crab larvae.

Additionally, various zoeal instars in larval development of decapod crustaceans (Criales \& Anger, 1986; Pestana \& Ostrensky, 1995) and immature megalopa (Dan, Kaneko, Takeshima, Ashidate \& Hamasaki, 2013) were also observed with feeding exclusively on Artemia nauplii. Morphological variation and formation of immature megalopa adversely affected the survival during transition from the Z5 to the megalopa stage, as evidenced by $2.2 \%$ of successful megalopa metamorphosis in this study, consistent with a previous study of Dan et al. (2013) in swimming crabs. Low eicosapentaenoic acid (EPA) levels in both newly hatched and starved Artemia could result in low survival and prolonged intermoult periods of $S$. serrata larvae (Suprayudi, Takeuchi \& Hamasaki, 2004) and P. trituberculatus larvae (Dan et al., 2016b). Therefore, it is also believed that feeding exclusive Artemia throughout the larval development cannot supply enough essential nutrients which are necessary for further larval development.

Extending inclusion of rotifers in the diets of mud crab larvae until Z5 stage significantly improved the survival and metamorphosis than when larvae were fed exclusive Artemia (control). However, there was no significant difference in survival and metamorphosis of mud crab larvae among the feeding regimes where rotifers were extended from Z2 to Z5 stages. Baylon et al. (2004) observed that the crab larvae increased ingestion of Artemia on the day before moulting, whereas ingestion of rotifers was increased one day after the moulting. As before the moulting, the larvae with a hard exoskeleton had higher nutrient requirements as they had to anabolise their tissues and should be strong active enough to catch and handle Artemia nauplii. On the other hand, immediately after the moulting, the larvae were weaker with a softer exoskeleton, thereby showing a limited ability to catch Artemia. Therefore, the larvae switched their dietary preference towards rotifers to accumulate more nutrient necessary that cannot get from Artemia nauplii (Baylon et al., 2004) for maintaining and recovering energy essential for the survival and development to the next stage. The fact that increased survival of the crab larvae as increasing extended feeding of rotifers could be due to continuous accumulation of nutrients derived from both rotifers and Artemia nauplii during the larval development period.

In addition, the co-existence of rotifers and Artemia in the rearing water could overcome the problem of Artemia starvation (Dan et al., 2016b) as Artemia starvation is prevented as Artemia can feed on rotifer excrement and/or on the proliferating bacterial populations established due to the presence of rotifer excrements (Dan et al., 2016b). This possibly induces morphological variation and immature megalopa, both causing high megalopa mortalities. Similarly, in the presence of Artemia, if rotifers are excluded at the Z1 or Z2 stages (Nghia 2004; Ruscoe et al., 2004b), starvation of Artemia may result. The feeding of starved nauplii to the late zoeal stages can adversely affect the survival and morphology of the successive stages of mud crab larvae (Dan et al., 2016b). In addition, in the current study, excessive Artemia could occur in the feeding regimes where exclusively Artemia (control regime) were used and extension of rotifers inclusion was stopped and replaced to Artemia at the early stages. The density of Artemia was increased similar to the control. The excessive Artemia can also result in a higher percentage failure rate of megalopa moulting (Suprayudi et al., 2002). Therefore, the feeding rotifer inclusion mixed with Artemia until the late zoeal stages, could limit the numbers of starved and excessive Artemia in the rearing water that could result in ensuring a progressive increase of survival and metamorphosis of the crab larvae.

The early zoeal stages can easily catch and ingest rotifers (Nghia, 2004) at a rate four times higher than that for Artemia, followed by the gradual reduction in the quantity of ingested rotifers to almost the quantity of ingested Artemia when the larvae reach the Z5 stage (Baylon et al., 2004). These authors also stated that the larvae at Z1, $\mathrm{Z} 2$ and Z3 stages had lower Artemia ingestion rates in the presence of rotifers in a combination with Artemia. By including rotifers in the feeding regimes of mud crab larvae, the Artemia usage was reduced by $50 \%$ without compromising survival and metamorphosis until Z4 stages of the mud crab. When rotifer inclusion was extended until Z5 stage, in the presence of Artemia, the survival and metamorphosis of megalopa was further improved.

Artemia cysts contribute more than $50 \%$ of the variable costs in any crab hatchery (Quinitio, Parado-Estepa, Millamena, Rodriguez \& Borlogan, 2001), extending the period of rotifer inclusion in the dietary regime for crab seed production could significantly improve the economic efficiency of the hatchery by making significant reduction in the usage of Artemia. In addition, mass and continuous rotifer production procedures (Kostopoulou 
et al., 2012; Lind, 2014) can be managed easily with a significantly reduced production cost.

We therefore suggest that prolonged inclusion of rotifers until the late zoeal stage, along with Artemia nauplii can improve the efficiency of mud crab hatchery production of megalopa. However, research is recommended to investigate whether the enrichment of the live feed, in the current version of the feeding regime, can further improve the survival and health of the crab larvae.

\section{Acknowledgments}

The authors wish to thank the Curtin International Postgraduate Research Scholarships (CIPRS) and the Ministry of Education and Training (MoET) of Vietnam Award for research support. My sincere gratitude to Mr Kha Tich $\mathrm{Vu}$ for supplying crab brood stocks, Mr. Vo Hong Hai for supporting all hatchery facilities, Mr. Vo Chi Thanh for the assistance in the hatchery and Mr. Hoang Thanh Lich for his help and support in culturing rotifers.

\section{References}

Barros, H. P., \& Valenti, W. C. (2003). Ingestion rates of Artemia nauplii for different larval stages of Macrobrachium rosenbergii. Aquaculture, 217, 223-233. https://doi.org/10.1016/S0044-8486(02)00229-6

Baylon, J. C. (2009). Appropriate food type, feeding schedule and Artemia density for the zoea larvae of the mud crab, Scylla tranquebarica (Crustacea: Decapoda: Portunidae). Aquaculture, 288, 190-195. https://doi.org/10.1016/j.aquaculture.2008.11.028

Baylon, J. C. (2010). Effects of salinity and temperature on survival and development of larvae and juveniles of the mud crab, Scylla serrata (Crustacea: Decapoda: Portunidae). Journal of the World Aquaculture Society, 41, 858-873. https://doi.org/10.1111/j.1749-7345.2010.00429.x

Baylon, J. C., \& Failaman, A. N. (1999). Larval rearing of the mud crab Scylla serrata in the Philippines. In: Keenan C. P., \& Blackshaw A. Mud Crab Aquaculture and Biology (pp. 141-146). ACIAR Proceedings, 78. ACIAR, Canberra, Australia.

Baylon, J. C., Bachoco, A. M., Huyo, M. P., \& Gallo, J. (1999). Prey density and feeding scheme using rotifer (brachionus plicatilis) and brine shrimp (Artemia salina) on survival and development from zoea to megalopa of the mud crab Scylla serrata (Crustacea: Portunidae). UPV Journal of Natural Science, 4, 21-31.

Baylon, J. C., Bravo, M. E. A., \& Maningo, N. C. (2004). Ingestion of Brachionus plicatilis and Artemia salina nauplii by mud crab Scylla serrata larvae. Aquaculture Research, 35, 62-70. https://doi.org/10.1111/j.1365-2109.2004.00987.x

Brick, R. W. (1974). Effects of water quality, antibiotics, phytoplankton and food on survival and development of larvae of Scylla serrata (Crustacea: Portunidae). Aquaculture, 3, 231-244. https://doi.org/10.1016/0044-8486(74)90074-X

Criales, M. M., \& Anger, K. (1986). Experimental studies on the larval development of the shrimps Crangon crangon and C. allmanni. Helgoländer Meeresuntersuchungen, 40, 241-265. https://doi.org/10.1007/bf01983735

Daintith, M. (1996). Rotifers and Artemia for marine aquaculture: a training guide. In: Walker, T., O'Sullivan, D. Aquaculture Sourcebook. University of Tasmania, Australia, p. 31.

Dan, S., Ashidate, M., \& Hamasaki, K. (2016a). Improved method for culturing the swimming crab Portunus trituberculatus larvae to prevent mass mortality during seed production. Fisheries Science, 82, 113-126. https://doi.org/10.1007/s12562-015-0935-y

Dan, S., Hamasaki, K., 2011. Effects of salinity and dietary n-3 highly unsaturated fatty acids on the survival, development, and morphogenesis of the larvae of laboratory-reared mud crab Scylla serrata (Decapoda, Portunidae). Aquaculture international, 19, 323-338. https://doi.org/10.1007/s10499-010-9374-z

Dan, S., Kaneko, T., Takeshima, S., Ashidate, M., \& Hamasaki, K. (2013). Variations in larval morphology and their relationships to survival during mass seed production by the swimming crab, Portunus trituberculatus (Brachyura, Portunidae). Aquaculture, 414-415, 109-118. https://doi.org/10.1016/j.aquaculture.2013.07.029

Dan, S., Oshiro, M., Ashidate, M., \& Hamasaki, K. (2016b). Starvation of Artemia in larval rearing water affects post-larval survival and morphology of the swimming crab, Portunus trituberculatus (Brachyura, Portunidae). Aquaculture, 452, 407-415. https://doi.org/10.1016/j.aquaculture.2015.06.004

Dat, H. D. (1999). Preliminary studies on rearing the larvae of the mud crab (Scylla paramamosain) in South 
Vietnam. In Keenan C. P., \& Blackshaw A. (Eds.), Mud Crab Aquaculture and Biology (pp. 147-152). ACIAR Proceedings, 78. ACIAR, Canberra, Australia.

Davis, J. A. (2003). Development of hatchery techniques for the mud crab Scylla serrata (Forskal) in South Africa (Doctoral dissertation). Retrieved from https://biblio.ugent.be/publication/521739

Davis, J. A., Wille, M., Hecht, T., \& Sorgeloos, P. (2005a). Optimal first feed organism for South African mud crab Scylla serrata (Forskaal) larvae. Aquaculture International, 13, 187-201. https://doi.org/10.1007/s10499-004-1496-8

Davis, J. A., Wille, M., Hecht, T., \& Sorgeloos, P. (2005b). Optimum time for weaning South African Scylla serrata (Forskål) larvae from rotifers to Artemia. Aquaculture International, 13, $203-216$. https://doi.org/10.1007/s10499-004-1915-x

Dhert, P. (1996). Rotifers. In: Lavens P., \& Sorgeloos P. (Eds), Manual on the Production and Use of Live Food for Aquaculture (pp. 49-78). FAO Technical Paper 1996. Food and Agriculture Organisation.

Faleiro, F., \& Narciso, L. (2009). Brachionus vs Artemia duel: Optimizing first feeding of Upogebia pusilla (Decapoda: $\quad$ Thalassinidea) larvae. $\quad$ Aquaculture, $205-208$. https://doi.org/10.1016/j.aquaculture.2009.07.008

Godfred, J., Ravi, A. V., \& Kannupandi, T. (1997). Larval feed preference of the estuarine edible portunid crab Thalamita crenata (Laterille). Indian Journal of Fisheries, 44, 69-74.

Hassan, A., Hai, T. N., Anil, C., \& Sukumaran, M. (2011). Preliminary Study on the Feeding Regime of Laboratory Reared Mud Crab Larva, Scylla serrata (Forsskal, 1775). World Applied Sciences Journal, 14, 1651-1654.

Heasman, M. P., \& Fielder, D. R. (1983). Laboratory spawning and mass rearing of the mangrove crab, Scylla serrata (Forskal), from first zoea to first crab stage. Aquaculture, 34, 303-316. https://doi.org/10.1016/0044-8486(83)90210-7

Holme, M. -H., Zeng, C., \& Southgate, P. C. (2006). Use of microbound diets for larval culture of the mud crab, Scylla serrata. Aquaculture, 257, 482-490. https://doi.org/10.1016/j.aquaculture.2006.03.014

Ikhwanuddin, M., Azra, M., Redzuari, A., Aizam, Z., \& Abol-Munafi, A. (2012). Ingestion rates of Brachionus sp. and Artemia sp. nauplii by Blue Swimming Crab, Portunus pelagicus (Linnaeus, 1758) larvae. Journal of Fisheries and Aquatic Science, 7, 402-411. https://doi.org/10.3923/jfas.2012.402.411

Ingle, R. (1997). Crayfishes, Lobsters and Crabs of Europe: an illustrated guide to common and traded species. London. 281pp.

Keenan, C. P. (1999a). Aquaculture of the mud crab, genus Scylla - Past, Present and Future. In: Keenan C. P., \& Blackshaw A. Mud Crab Aquaculture and Biology (pp. 9-13). ACIAR Proceedings, 78. ACIAR, Canberra, Australia.

Keenan, C. P. (1999b). The Fourth Species of Scylla. In: Keenan C. P., \& Blackshaw A. Mud Crab Aquaculture and Biology (pp. 48-58). ACIAR Proceedings, 78. ACIAR, Canberra, Australia.

Keenan, C. P., Davie, P. J. F., \& Mann, D. L. (1998). A revision of the genus Scylla de Haan, 1833 (Crustacea: Decapoda: Brachyura: Portunidae). The Raffles Bulletin of Zoolozy, 46, 217-245.

Kostopoulou, V., Vasilakis, M., \& Divanach, P. (2012). Semi-continuous mass culture of rotifers (Brachionus plicatilis) using an automatic feeder. Aquaculture Research, 43, 91-98. https://doi.org/10.1111/j.1365-2109.2011.02807.x

Li, S., Zeng, C., Tang, H., Wang, G., \& Lin, Q. (1999). Investigations into the reproductive and larval culture biology of the mud crab, Scylla paramamosain. In: Keenan, C.P., Blackshaw, A. A. Mud Crab Aquaculture and Biology (pp. 121-124). ACIAR Proceedings, vol. 78. ACIAR, Canberra, Australia.

Lind, R. D. (2014). Effects of selected commercial diets and yeast substitution on the growth and associated microbiota of rotifer (Brachionus plicatilis) (Master's thesis). Retrieved from http://scholarlyrepository.miami.edu/cgi/viewcontent.cgi?article=1541\&context=oa_theses

Mann, D., Asakawa, T., \& Pizzutto, M. (1999). Development of a hatchery system for larvae of the mud crab Scylla serrata at the Bribie Island Aquaculture Research Centre. In: Keenan, C. P., \& Blackshaw, A. Mud Crab Aquaculture and Biology (pp. 153-158). ACIAR Proceedings, vol. 78. ACIAR, Canberra, Australia.

Nghia, T. T. (2004). Optimization of mud crab (Scylla paramamosain) larviculture in Vietnam (Doctoral 
dissertation). Retrieved from https://biblio.ugent.be/publication/2067929

Nghia, T. T., Wille, M., Binh, T. C., Thanh, H. P., Danh, N. V., \& Sorgeloos, P. (2007). Improved techniques for rearing mud crab Scylla paramamosain (Estampador, 1949) larvae. Aquaculture Research, 38, 1539-1553. https://doi.org/10.1111/j.1365-2109.2007.01814.x

Pestana, D., \& Ostrensky, A. (1995). Occurrence of an alternative pathway in the larval development of the crab Chasmagnathus granulata Dana, 1851 under laboratory conditions. Hydrobiologia, 306, 33-40. https://doi.org/10.1007/bf00007856

Quinitio, E. T., Parado-Estepa, F. D., \& Alava, V. (1999). Development of hatchery techniques for the mud crab Scylla serrata (Forskal): Comparison of feeding schemes. In Keenan C. P., \& Blackshaw A. Mud Crab Aquaculture and Biology (pp. 125-130). ACIAR Proceedings, vol. 78. ACIAR, Canberra, Australia.

Quinitio, E. T., Parado-Estepa, F. D., Millamena, O. M., Rodriguez, E., \& Borlongan, E. (2001). Seed production of mud crab, Scylla serrata juveniles. Asian Fisheries Science, 14, 161-174.

Redzuari, A., Azra, M., Abol-Munafi, A., Aizam, Z., Hii, Y., \& Ikhwanuddin, M. (2012). Effects of feeding regimes on survival, development and growth of blue swimming crab, Portunus pelagicus (Linnaeus, 1758) larvae. World Applied Science Journal, 18, 472-478. https://doi.org/10.5829/idosi.wasj.2012.18.04.313

Ruscoe, I. M., Shelley, C. C., \& Williams, G. R. (2004a). The combined effects of temperature and salinity on growth and survival of juvenile mud crabs (Scylla serrata Forskål). Aquaculture, 238, 239-247. http://dx.doi.org/10.1016/j.aquaculture.2004.05.030

Ruscoe, I. M., Williams, G. R., \& Shelley, C. C. (2004b). Limiting the use of rotifers to the first zoeal stage in mud crab (Scylla serrata Forskål) larval rearing. Aquaculture, 231, 517-527. http://dx.doi.org/10.1016/j.aquaculture.2003.11.021

Suprayudi, M. A., Takeuchi, T., \& Hamasaki, K. (2004). Effects of Artemia enriched with eicosapentaenoic and docosahexaenoic acid on survival and occurrence of molting failure in megalop larvae of the mud crab Scylla serrata. Fisheries Science, 70, 650-658. https://doi.org/10.1111/j.1444-2906.2004.00853.x

Suprayudi, M. A., Takeuchi, T., Hamasaki, K., \& Hirokawa, J. (2002). Effect of Artemia feeding schedule and density on the survival and development of larval mud crab Scylla serrata. Fisheries Science, 68, 1295-1303. https://doi.org/10.1046/j.1444-2906.2002.00567.x

Vietnam (2013). National shrimp exports fall into muddy waters (Asia News Monitor). Retrieved from https://search-proquest-com.dbgw.lis.curtin.edu.au/docview/1266234573?accountid=10382

Yi, S. K., Lee, S. G., \& Lee, J. M. (2009). Preliminary study of seed production of the micronesian mud crab Scylla serrata (Crustacea: Portunidae) in Korea. Ocean and Polar Research, 31, 257-264. https://doi.org/10.4217/OPR.2009.31.3.257

Zar, J. H. (2010). Biostatistical Analysis, $5^{\text {th }}$ ed. Prentice Hall, USA, 670pp.

Zeng, C., \& Li, S. (1999). Effects of density and different combinations of diets on survival, development, dry weight and chemical composition of larvae of the mud crab Scylla paramamosain. In Keenan C. P., \& Blackshaw A. (Eds.), Mud Crab Aquaculture and Biology (pp. 159-166). ACIAR Proceedings, 78. ACIAR, Canberra, Australia.

Zeng, C., Li, S., \& Zeng, H. (2004). Occurrence of additional Zoea-VI larvae in the mud crab, Scylla paramamosain (Estampador), reared in the laboratory. Hydrobiologia, 529, 49-58. http://dx.doi.org/10.1007/s10750-004-4946-4

\section{Copyrights}

Copyright for this article is retained by the author(s), with first publication rights granted to the journal.

This is an open-access article distributed under the terms and conditions of the Creative Commons Attribution license (http://creativecommons.org/licenses/by/4.0/). 